\title{
Dry Mass Yield and Bromatological Composition of the Forage of Cynodon dactylon cv. Vaquero Submitted to Crescent Doses of Nitrogen, Applied as Swine Waste
}

\author{
João Paulo Fonesi de Carvalho ${ }^{1}$, Magno Daniel Porfirio ${ }^{1}$, Tauane Santos Brito ${ }^{2}$, Bruna Broti Rissato ${ }^{3}$, \\ Nelson Massaru Fukumoto ${ }^{4} \&$ Eduardo Eustáquio Mesquita ${ }^{5}$ \\ ${ }^{1}$ Postgraduate Program in Zootechnics, State University of the West of Paraná, Marechal Cândido Rondon, PR, \\ Brazil \\ ${ }^{2}$ Postgraduate Program in Agronomy, State University of the West of Paraná, Marechal Cândido Rondon, PR, \\ Brazil \\ ${ }^{3}$ Postgraduate Program in Agronomy, State University of the Maringá, Maringá, PR, Brazil \\ ${ }^{4}$ Teacher of the Course of Agronomy in the Institution, Pontifical Catholic University of Parana, Toledo, PR, \\ Brazil \\ ${ }^{5}$ Teacher of the Course of Agronomy in the Institution, State University of the West of Paraná, Marechal Cândido \\ Rondon, PR, Brazil
}

Correspondence: João Paulo Fonesi de Carvalho, Postgraduate Program in Zootechnics, State University of the West of Paraná, Marechal Cândido Rondon, PR, Brazil. E-mail: joao.fonesi@hotmail.com

Received: May 4, $2019 \quad$ Accepted: July 1, $2019 \quad$ Online Published: September 15, 2020

doi:10.5539/jas.v12n10p324 URL: https://doi.org/10.5539/jas.v12n10p324

\begin{abstract}
The present had as its objective to evaluate the response of dry mass total yield, and bromatological composition of the forage, submitted to different nitrogen doses, applied as swine waste in the pasture of Cynodon dactylon cv. 'Vaquero'. The study was developed during the period of November 2017 until March 2018, in the experimental area of the 'Pontifícia Universidade Católica do Paraná', campus Toledo, located in the western region of Paraná, under latitude $24^{\circ} 43^{\prime} 13^{\prime \prime} \mathrm{S}$ and longitude $53^{\circ} 47^{\prime} 01^{\prime \prime} \mathrm{W}$. The experimental design adopted was of randomized blocks with six treatments $\left(0,50,100,150,200\right.$ and $\left.250 \mathrm{~kg} \mathrm{ha}^{-1}\right)$ constituted by crescent doses of nitrogen as swine waste, with five replicates, totalizing 30 experimental plots. It was studied the dry mass yield $\left(\mathrm{kg} \mathrm{ha}^{-1}\right)$, crude protein (CP), dry mass (DM), neutral detergent fiber (NDF), acid detergent fiber (ADF), insoluble nitrogen in neutral detergent (NDIN), insoluble nitrogen in acid detergent (ADIN), lignin, ether extract (EE) and mineral matter (MM). It was verified that the $\mathrm{N}$ doses influenced in the dry mass yield of the forage, because it reached a productivity of $4520.57 \mathrm{~kg} \mathrm{ha}^{-1}$ in the dry mass. The highest crude protein content of 'Vaquero' was obtained with the dose of $250 \mathrm{~kg} \mathrm{ha}^{-1}$ of nitrogen, in which was observed a content of $13.72 \mathrm{~g} \mathrm{~kg}^{-1} \mathrm{of} \mathrm{CP}$ in the dry mass. The different nitrogen doses, applied as swine waste in the pasture of grass 'Vaquero', have an influence in the bromatological composition and in the dry mass yield, causing an increase in the forage contents of crude protein (CP), dry mass (DM), ether extract (EE), in forage produced under four cutting periods. The increase in the nitrogen doses improves the nutritional quality of grass 'Vaquero', once it causes decreases in the NDF and ADF content and increases in the CP and DM content.
\end{abstract}

Keywords: height, crude protein, nutritional quality

\section{Introduction}

Cultivated pasture exhibit a fundamental role in the cattle production (Santana et al., 2010), because they constitute a source of nutrients, from the pasture, to the animals (Camargo et al., 2011). The gramineous from the genus Cynodon have characteristics of high dry mass yield, a good nutritional value, notable for presenting species with high adaptation to the edaphoclimatic conditions (Oliveira et al., 2013).

However, it is indispensable the establishment of standards for the correct management practices, so then they will contribute for the pastures perenniality and, so that can happen, it is necessary knowledge about the morphophysiological characteristics of the gramineous pasture (Rodrigues et al., 2012). 
The use of fertilization is of huge importance since it has an influence in the vegetative growth, in the yield potential and the nutritional value of a pasture. In this sense, the nitrogen fertilization promotes a fast growth, increases the number of new leaves, raises the protein content and influence in the microorganism activity which decomposes the organic matter (Barbero et al., 2010).

Pastures with low crude protein and minerals content, and high fibers content are characterized as low nutritive value forage (Gerdes, 2000). Thus, the knowledge of the dry mass content (DM), crude protein content (CP), neutral detergent fiber (NDF), acid detergent fiber (ADF) and lignin are relevant in the pasture evaluation (Neto et al., 2000).

The swine waste is an alternative to fertilize the soil, making nutrients available to the plants, when managed correctly, contributing for the food production in the same way that it avoids harms to the environment (Klaus et al., 2013).

Due to this contribution to plants development, the application of liquid swine waste in a farm influences in the soil chemical composition, replacing the elements that were extracted from the crops or replacing the agricultural inputs which are recommended in the fertilization programs (Arruda et al., 2010).

The objective of the research was to evaluate the yield response in the forage dry mass and its bromatological composition, submitted to different nitrogen doses in the form of swine waste in the pasture of Cynodon dactylon cv. Vaquero.

\section{Material and Methods}

The study was developed from November 2017 until March 2018, in the experimental area of the 'Pontifícia Universidade Católica do Paraná', campus Toledo, located in the western region of Paraná under latitude $24^{\circ} 43^{\prime} 13^{\prime \prime} \mathrm{S}$ and longitude $53^{\circ} 47^{\prime} 01^{\prime \prime} \mathrm{W}$, with altitude of $575 \mathrm{~m}$.

Before the experiment was implanted, a soil analysis was made in the $0-20$ layer, obtaining the following characteristics $\mathrm{pH}\left(\mathrm{CaCl}_{2}\right)=5.04$; O.M. $\left(\mathrm{g} \mathrm{dm}^{-3}\right)=16.40 ; \mathrm{P}\left(\mathrm{mg} \mathrm{dm}^{-3}\right)=12.69 ; \mathrm{K}^{-3}\left(\mathrm{cmolc} \mathrm{dm}^{-3}\right)=0.35 ; \mathrm{Ca}$ $\left(\mathrm{cmolc} \mathrm{dm}^{-3}\right)=4.04 ; \mathrm{Mg}\left(\mathrm{cmolc} \mathrm{dm}^{-3}\right)=1.07 ; \mathrm{Cu}\left(\mathrm{mg} \mathrm{dm}^{-3}\right)=4.90 ; \mathrm{Zn}\left(\mathrm{mg} \mathrm{dm}^{-3}\right)=1.81 ; \mathrm{Mn}\left(\mathrm{mg} \mathrm{dm}^{-3}\right)=$ 105.99; $\mathrm{Fe}\left(\mathrm{mg} \mathrm{dm}^{-3}\right)=25.7 ; \mathrm{H}+\mathrm{Al}\left(\mathrm{cmolc} \mathrm{dm}^{-3}\right)=3.59 ; \mathrm{BS}\left(\mathrm{cmolc} \mathrm{dm}^{-3}\right)=5.46 ; \mathrm{T}\left(\mathrm{cmolc} \mathrm{dm}^{-3}\right)=9.05$ and $\mathrm{V}(\%)=60.35$. The soil in the area is classified as Oxisol with clay texture (EMBRAPA, 2006).

According to the Köppen classification, the weather is classified as subtropical Cfa, with hot summers, frosts and tendency to rainfall concentration in the summer months, however with non-defined dry season. The average temperatures in the coldest quarter vary between 17 and $18^{\circ} \mathrm{C}$, and from the hottest quarter between 28 and 29 ${ }^{\circ} \mathrm{C}$. The normal total average rainfall for the region ranges from 1800 to $2000 \mathrm{~mm}$ (IAPAR, 2013).

Table 1. Monthly average of the maximum, minimum and average temperatures, accumulated rainfall and the number of days of precipitation during the months of the experimental period

\begin{tabular}{lllllll}
\hline \multirow{2}{*}{ Months } & \multicolumn{3}{c}{ Temperature } & & \multicolumn{2}{c}{ Precipitation } \\
\cline { 2 - 4 } & Maximum & Minimum & Average & & Volume $(\mathrm{mm})$ & Days of Precipitation \\
\hline November & 29 & 17 & 23 & & 217 & 12 \\
December & 30 & 20 & 25 & & 301 & 17 \\
January & 30 & 20 & 25 & & 339 & 17 \\
February & 32 & 19 & 25,5 & & 309 & 11 \\
March & 32 & 21 & 26,5 & & 233 & 14
\end{tabular}

Source: Meteorological station of the 'Pontifícia Universidade Católica do Paraná', in the city of Toledo-PR, in 2017 and 2018.

The grass 'Vaquero' was already planted in the experimental area, its past use was to produce hay. In 11/10/2017 it was cut and uniformized, with aid of mower, plants were cut at $0.05 \mathrm{~m}$ in relation to the soil surface and, the material obtained with the cut, was removed with a garden rake. Finishing the cut, the area was delimited, and the experimental plots were dimensioned with wooden stakes.

The experimental design adopted was of randomized blocks with six treatments $(0,50,100,150,200,250 \mathrm{~kg}$ $\mathrm{ha}^{-1}$ ) per cut constituted of growing doses of nitrogen in the form of swine waste, with five replicates, totalizing 30 plots. Each experimental plot had $4 \mathrm{~m}^{2}(2 \times 2 \mathrm{~m})$. 
Thirty days after the uniformization cut, the first evaluation of the grass 'Vaquero' was made, with the following ones being made in an interval of 30 days, totalizing four cut periods. After each cut realized for the evaluations, it was repeated the nitrogen fertilization, in function of doses applied as swine waste. A graduated bucket was used to measure the wastes volume to be applied, in different doses in the plots, according to their respective treatment (Table 2).

The application was made with a watering can with rose, so the liquid was poured in a shower. The swine wastes used for the fertilization were removed from a biodigester of a swine production farm. The property is located next to the experimental area.

The waste was transported from the farm to the experimental area with a 4000 liters waste distributor tank. After transport, the material was homogenized, being about 2 liters separated for lab analysis.

Table 2. Amount of nitrogen $\left(\mathrm{t} \mathrm{ha}^{-1}\right)$ as swine waste $\left(\mathrm{L} \mathrm{ha}^{-1}\right)$, applied in four cut periods

\begin{tabular}{|c|c|c|c|c|}
\hline \multirow{2}{*}{ Nitrogen } & \multicolumn{4}{|c|}{ Application of swine waste (cut) } \\
\hline & $1^{\text {st }}$ & $2^{\text {nd }}$ & $3^{\text {rd }}$ & $4^{\text {th }}$ \\
\hline ------------ t ha"1 ------------ & \multicolumn{4}{|c|}{ 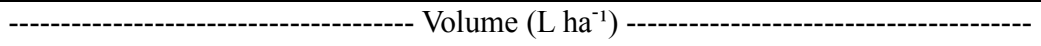 } \\
\hline 0 & 0 & 0 & 0 & 0 \\
\hline 50 & 2.28 & 3.40 & 4.90 & 7.55 \\
\hline 100 & 4.56 & 6.80 & 9.80 & 15.10 \\
\hline 150 & 6.84 & 10.20 & 14.70 & 22.50 \\
\hline 200 & 9.12 & 13.60 & 19.60 & 30.00 \\
\hline 250 & 11.40 & 17.00 & 24.50 & 37.50 \\
\hline
\end{tabular}

Source: The author, 2018.

The lab analysis was made in the 'Laboratório de Análise Ambientais e Agronômicas' in Campo Mourão-Paraná. The nitrogen concentration from the waste's analysis in the four cut periods are shown on Table 3. The determination of the amount to be applied in the plots was based in the nitrogen content of the waste analyzed.

Table 3. Nitrogen concentration in the analysis of the swine wastes applied in the four cut periods.

\begin{tabular}{llllll}
\hline Parameters & Units & 1st cut & 2nd cut & 3rd cut & 4th cut \\
\hline $\mathrm{N}$ & $\mathrm{g} \mathrm{kg}^{-1}$ & 8.68 & 5.85 & 4.03 & 2.63 \\
\hline
\end{tabular}

Source: Laboratory of ‘Análises Ambientais e Agronômicas’ of Campo Mourão-PR.

In the sampling two metal squares of $0.5 \times 0.5 \mathrm{~m}\left(0.25 \mathrm{~m}^{2}\right)$ were used, which were randomly thrown on each experimental plot. After thrown, all the plants inside the square were collected, being the cut made with a scythe.

After every collection the plants were packed in plastic bags, taken to the animal nutrition lab from the "Pontifícia Universidade Católica do Paraná", and weighted for the fresh mass obtainment.

After weighing, one subsample of $200 \mathrm{~g}$ was stored in paper bags and taken to an air forced circulation oven at $55{ }^{\circ} \mathrm{C}$ for 72 hours for the dry mass determination (Silva \& Queiroz, 2006). The total dry mass yield was obtained by the multiplication of the fresh mass yield for the dry mass content.

The material from the oven were mowed in an Willey type mower, with $1 \mathrm{~mm}$ sieve, after the material was mowed it was stored into identified plastic containers for posterior chemical analysis, for the determination of: dry mass content (DM), crude protein (CP), ether extract (EE) and ashes (AS), according to the methodology described by AOAC (1990) and neutral detergent fiber (NDF), acid detergent fiber (ADF) and lignin following the methodology describe by Van Soest et al. (1991). The samples from the NDF and ADF analyses allowed the evaluation of insoluble nitrogen in neutral detergent (NDIN) and insoluble nitrogen in acid detergent (ADIN).

From the data obtained were calculated the average values for the four periods evaluated, about the effect of the nitrogen doses in productivity and in the bromatological composition, by means of regression analysis, testing the linear and quadratic models. For the choice of the model, it was considered the parameters significance $(\mathrm{P}<$ 0.05 ) and the determination coefficient $\left(\mathrm{R}^{2}\right)$. All analysis was made with the software SigmaPlot 12.0 (Systat Software, 2011). 


\section{Results and Discussion}

\subsection{Dry Mass and Mineral Matter}

The values of dry mass from the grass 'Vaquero' adjusted to the crescent linear model, in function of $\mathrm{N}$ doses, and ranged from 28.66 up to $31.66 \mathrm{~g} \mathrm{~kg}^{-1}$ in the aerial part. The dry mass contents (DM) were influenced by the nitrogen doses, an increase in the DM content was observed in response to the nitrogen doses.

Every $50 \mathrm{~kg} \mathrm{ha}^{-1}$ of nitrogen applied an increase of $0.6 \mathrm{~g} \mathrm{~kg}^{-1}$ in the dry mass percentage of the grass 'Vaquero' occur according to the first-degree equation (Figure 1). This increase in the dry mass percentage possibly occur due to the higher availability of nitrogen, which stimulates the forage's growth. The availability of nitrogen provides an increase in the growth and development of grasses, mainly resulting in a fast formation of axillary buds, tiller emission and, consequently, a better development of plants (Vitor et al., 2009).

According to Taiz and Zeiger (2013), the nitrogen is fundamental for the protein synthesis to occur and the enzymes activation, for the plant production, formation of new tissues and, consequently, an increase in the plant's nutritional quality.

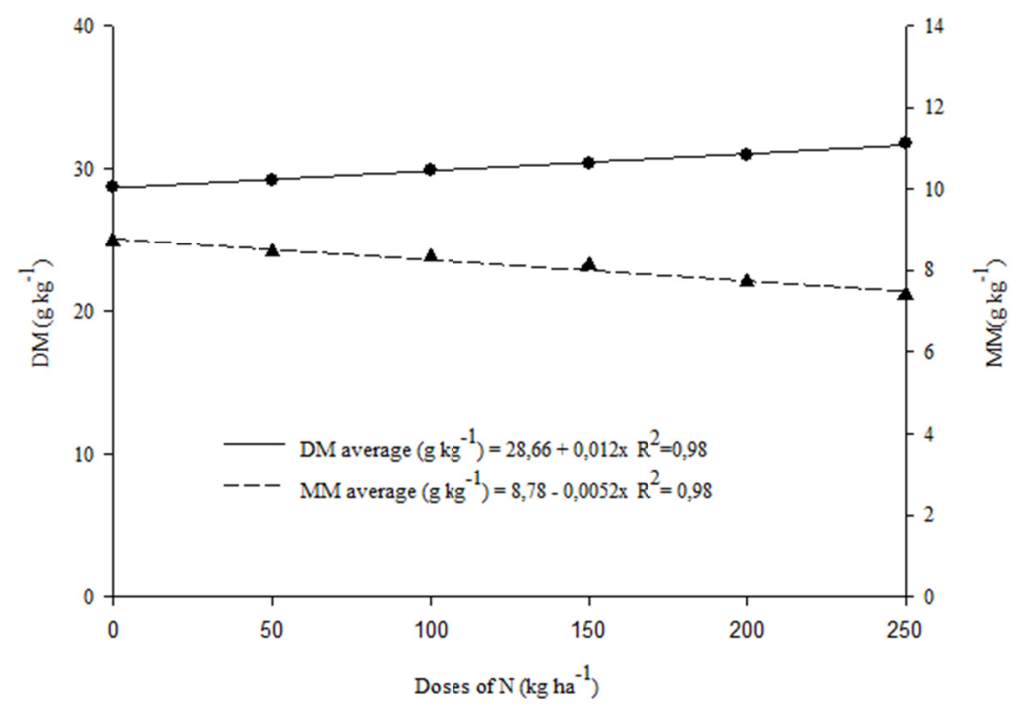

Figure 1. Average values of DM and MM of 'Vaquero' forage as a function of nitrogen (N) doses, applied as swine waste, in four periods of forage growth

The dry mass contents obtained in the present study were superior to the ones found by Castagnara et al. (2011a), studying the effects of nitrogen fertilization $\left(0,40,80,120\right.$ and $\left.160 \mathrm{~kg} \mathrm{ha}^{-1}\right)$, in tropical grasses, found significant effects with the application of nitrogen to the launch, with intervarls of cut, fertilization having as a source of $\mathrm{N}$ the urea, obtained an average DM content for the grasses 'Tanzania' of $23.50 \mathrm{~g} \mathrm{~kg}^{-1}$, 'Mombaça' with $23.50 \mathrm{~g}$ $\mathrm{kg}^{-1}$ and the 'Mulato' with $24.08 \mathrm{~g} \mathrm{~kg}^{-1}$.

The grass 'Vaquero' presented a decrescent linear behavior for the mineral matter (MM) content, which ranged from 6.48 up to $8.78 \mathrm{~g} \mathrm{~kg}^{-1}$ in the aerial part, that is, inversely proportional to the increasing doses of nitrogen. The lower MM contents were in the dose of $250 \mathrm{~kg} \mathrm{ha}^{-1}$ of nitrogen, with $6.48 \mathrm{~g} \mathrm{~kg}^{-1}$.

In this study the grass 'Vaquero' presented inferior contents of MM to the ones found by Fukumoto et al. (2010), that studied tropical grasses, obtained MM average contents of $12 \mathrm{~g} \mathrm{~kg}^{-1}$ for the 'Tanzania' forage, of $9 \mathrm{~g} \mathrm{~kg}^{-1}$ for the 'Estrela' and of $9.7 \mathrm{~g} \mathrm{~kg}^{-1}$ for the 'Marandu' forage. High mineral matter contents in grasses may be caused due to forage species of other genus.

Inferior results were obtained by Carvalho et al. (2011), that evaluated the nutritional value of the grass from the genus Brachiaria, found MM contents of $9.1 \mathrm{~g} \mathrm{~kg}^{-1}$ for Brachiaria brizantha $\mathrm{cv}$, Marandu, obtained from the manual grazing simulation.

On the other hand, Gonçalves et al. (2001), studying grasses from the genus Cynodon, in different cutting periods, obtained mineral matter contents ranging from 6.62 up to $8.20 \mathrm{~g} \mathrm{~kg}^{-1}$ in DM, similar to the ones found in this study. 


\subsection{Crude Protein}

The crude protein content in the grass 'Vaquero' had a better adjustment to the growing linear model, in function of the nitrogen doses, which confirms the dose-dependent nature of the forage plant. Thus, the higher crude protein value was obtained with the dose of $250 \mathrm{~kg} \mathrm{ha}^{-1}$ of nitrogen, with $13.71 \mathrm{~g} \mathrm{~kg}^{-1}$, that is, an increase of $37.65 \%$ in the crude protein content.

The grass 'Vaquero' presented crude protein contents over $7 \mathrm{~g} \mathrm{~kg}^{-1}$, which corroborates with Van Soest (1994), who related that CP contents over $7 \mathrm{~g} \mathrm{~kg}^{-1}$ make viable the forage consumption. The same author reports that values lower than this percentual can limit the nutrients digestibility and decrease the intake of bulky foods.

The values found in this study for the grass 'Vaquero' are inferior to the ones found by Andrade et al. (2012), that while studying this forage found an average content of $21.70 \mathrm{~g} \mathrm{~kg}^{-1}$, protein contents considered. Also, the crude protein results obtained are similar to the ones found by Mistura et al. (2007) when evaluating crescent doses of nitrogen $\left(100,200,300\right.$ and $\left.400 \mathrm{~kg} \mathrm{ha}^{-1}\right)$ in the bromatological composition of Pennisetum purpureum obtained values of $10.32 ; 11.32 ; 12.32$ and $13.32 \mathrm{~g} \mathrm{~kg}^{-1}$.

In the crude protein content of the grass 'Vaquero', there was an increase of $0.75 \mathrm{~g} \mathrm{~kg}^{-1}$ with the addition of 50 $\mathrm{kg} \mathrm{ha}^{-1}$ of nitrogen (Figure 2). This increase in the crude protein content of the grasses from the genus Cynodon are due to the increase in the nitrogen doses (Rocha et al., 2012). According to Moreira et al. (2009), the increase in the forage protein content is related to the nitrogen fertilization, and the low availability of the nutrient influences the quality of the pasture.

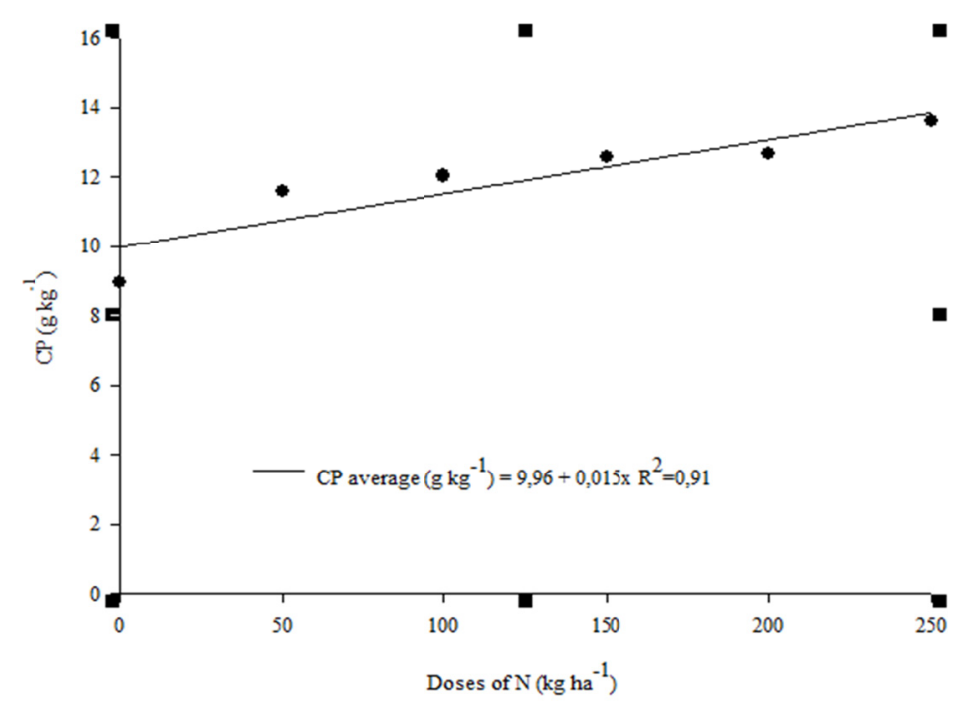

Figure 2. Average content of CP in the dry mass of forage 'Vaquero' in function of nitrogen doses $(\mathrm{N})$, applied as swine waste in four growing periods of the forage

In the treatment of $250 \mathrm{~kg} \mathrm{ha}^{-1}$ a higher average crude protein content was obtained, in which was found a content of $13.71 \mathrm{~g} \mathrm{~kg}^{-1}$ of CP in the dry mass. The values obtained were lower than those obtained by Andrade et al. (2012) with average protein content of $23.74 \mathrm{~g} \mathrm{~kg}^{-1}$ for the 'Vaquero', of $23.45 \mathrm{~g} \mathrm{~kg}^{-1}$ for the 'Tifton 85 ' during summer time, using in the experiment nitrogen fertilization based in the pasture nutritional balance seeking a forage increase of $30 \mathrm{tha}^{-1}$.

High crude protein contents are desirable to supply the protein demands from the ruminants, since the pasture is the most economical way to attend the crude protein contents (Andrade et al., 2012).

The values obtained remained similar to the ones obtained by Rocha et al. (2000), who evaluated the effects of nitrogen doses in the average CP content (\%), of the forages 'Coastcross', 'Tifton 68' and 'Tifton 85', reached average levels of $11.73 \mathrm{~g} \mathrm{~kg}^{-1}$ for the 'Coastcross', $11.38 \mathrm{~g} \mathrm{~kg}^{-1}$ for the 'Tifton 68 ' and $11.69 \mathrm{~g} \mathrm{~kg}^{-1}$ for the 'Tifton 85 '. 


\subsection{Neutral Detergent Fiber (NDF) and Indigestible Nitrogen in Acid Detergent (NDIN)}

The NDF contents exhibited a linear negative behavior, with a decrease in the NDF, with increases in the nitrogen doses. The NDF contents in the control $\left(0 \mathrm{~kg} \mathrm{ha}^{-1}\right)$ were the highest, it may be explained because the nitrogen fertilization was made in the beginning of the summer growth period and the cuts were always made with a growth interval of 30 days (during summer time the forage growth speed is higher, consequently, higher the production of leaf blades), in which corroborates with Gerdes et al. (2000).

In the average of all cuts, the NDF content decreased with the nitrogen fertilization, from 71.63 to $63.88 \mathrm{~g} \mathrm{~kg}^{-1}$, from the lower to the higher dose, respectively. These content results of NDF coincide with the results found in the work of Vitor et al. (2009), where the contents also decreased with the increase in the nitrogen fertilization, from 76.9 to $72.0 \mathrm{~g} \mathrm{~kg}^{-1}$ of DM.

According to Vitor et al. (2009), the nitrogen fertilization can reduce the plant's NDF percentage of plants to stimulate the growth of forage, influencing in the formation of new tissues. The NDF content is extremely important for the forage because it presents correlation with the dry mass consumption. NDF values superior to 55 to $60 \mathrm{~g} \mathrm{~kg}^{-1}$ limit the consumption of dry mass, because they cause a filling effect in the rumen (Van Soest, 1994).

The NDF results were inferior to the reported by Mistura et al. (2007), studying the effect of the nitrogen fertilization $\left(100,200,300\right.$ and $\left.400 \mathrm{~kg} \mathrm{ha}^{-1}\right)$ over the bromatological composition of Pennisetum purpureum, found NDF contents between $75.39 \%$ for the dose of $100 \mathrm{~kg} \mathrm{ha}^{-1}$ and $77.49 \mathrm{~g} \mathrm{~kg}^{-1}$ for the dose of $400 \mathrm{~kg}$ $\mathrm{ha}^{-1}$.Superior results were found for the genus Panicum by Mesquita and Neres (2008), in which the cultivars of Panicum maximum submitted to crescent doses of N, reduced the NDF contents, which reached contents of $74.25 \mathrm{~g} \mathrm{~kg}^{-1}$ for the forage 'Tanzania'; $74.27 \mathrm{~g} \mathrm{~kg}^{-1}$ for the forage 'Mombaça'.

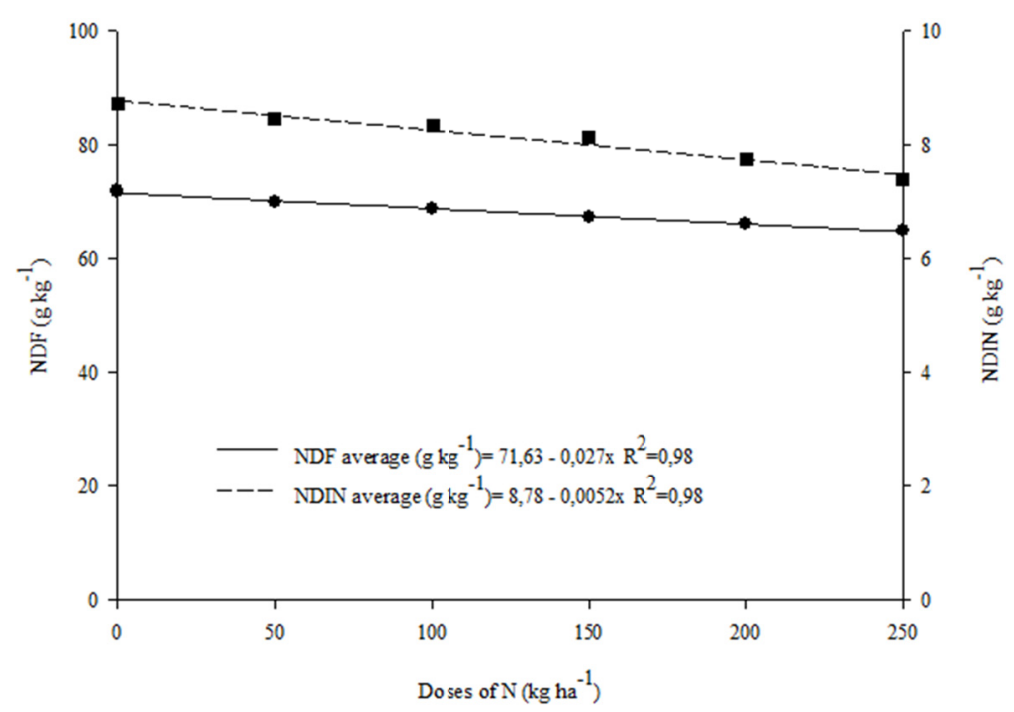

Figure 3. Average content of NDF and NDIN in the forage dry mass of 'Vaquero' in function of nitrogen (N) doses, applied as swine waste, in four growth periods of the forage

The NDF behavior corroborates with the studies of Vitor et al. (2009), who evaluated the Pennisetum purpureum response to crescent doses of nitrogen $\left(100,300,500\right.$ and $\left.700 \mathrm{~kg} \mathrm{ha}^{-1}\right)$, were able to observe that the values decreased with the nitrogen fertilization, all year long, ranging from 73.00 to $74.48 \mathrm{~g} \mathrm{~kg}^{-1} \mathrm{NDF}$.

According to Magalhães et al. (2012), the nitrogen reduces the NDF content because it stimulates the growth of new tissues and, influences in the formation of constituents of the cell wall.

The indigestible nitrogen content in neutral detergent (NDIN) in the grass 'Vaquero', adjusted to the negative linear model in function of nitrogen doses. In the average of all cuts, the NDIN content decreased with the nitrogen fertilization, raging between 7.48 to $8.78 \mathrm{~g} \mathrm{~kg}^{-1}$. According to Pereira et al. (2010) the indigestible nitrogen in neutral detergent (NDIN), constitutes the nitrogen fraction that is made available slowly in the rumen of the animal. 
The results are in accordance with the values observed by Silva et al. (2013), who found values of $7.31 \mathrm{~g} \mathrm{~kg}^{-1} \mathrm{of}$ NDIN in all plant, studying the chemic-bromatological composition of different fractions of Stylosanthes spp. cv. 'Campo Grande'.

Despite the estimated contents of NDF had surpassed the limit values of $70 \mathrm{~g} \mathrm{~kg}^{-1}$, associated to it, there are reduced concentrations of NDIN, which reflect the better quality of the forage, because the smaller the NDIN, the greater the availability of $\mathrm{N}$ and, consequently, the $\mathrm{CP}$, improving the forage digestibility (SILVA et al., 2013).

The NDIN were inferior to the ones reported by Castagnara et al (2011a), that studying the grass 'Tifton 85 ' in winter time, found NDIN content of $6.8 \mathrm{~g} \mathrm{~kg}^{-1}$ at 42 days of regrowth, inferior values to the ones found in this study with 'Vaquero' forage.

\subsection{Acid Detergent Fiber (ADF) and Indigestible Nitrogen in Acid Detergent (ADIN)}

As well as the NDF content, the acid detergent fiber content (ADF) was also influenced by the nitrogen fertilization. The ADF and ADIN content exhibited a linear negative behavior and, decreasing with the increases in the nitrogen dose (Figure 4).

In the average of all cuts, the ADF content decreased with the nitrogen fertilization, with values of $35.9 \mathrm{~g} \mathrm{~kg}^{-1}$; $35.15 \mathrm{~g} \mathrm{~kg}^{-1} ; 34.4 \mathrm{~g} \mathrm{~kg}^{-1} ; 33.65 \mathrm{~g} \mathrm{~kg}^{-1} ; 32.90 \mathrm{~g} \mathrm{~kg}^{-1}$ and $32.15 \mathrm{~g} \mathrm{~kg}^{-1}$, respectively for the nitrogen doses studied $\left(0,50,100,150,200\right.$ and $\left.250 \mathrm{~kg} \mathrm{ha}^{-1}\right)$.

The reduction in the ADF content, with the increase in the doses of $\mathrm{N}$ applied, may be explained because the nitrogen is responsible for the forage growth, reducing the stem formation (Costa et al., 2010).

The ADF behavior in the stem fraction compared to the leaf was similar to the one found by Marchesan et al. (2013), reached ADF average content between 31.65 and $41.48 \mathrm{~g} \mathrm{~kg}^{-1}$, in the structures of leaves and stems, in the chemic-bromatological composition of the forage 'Tifton 85 '.

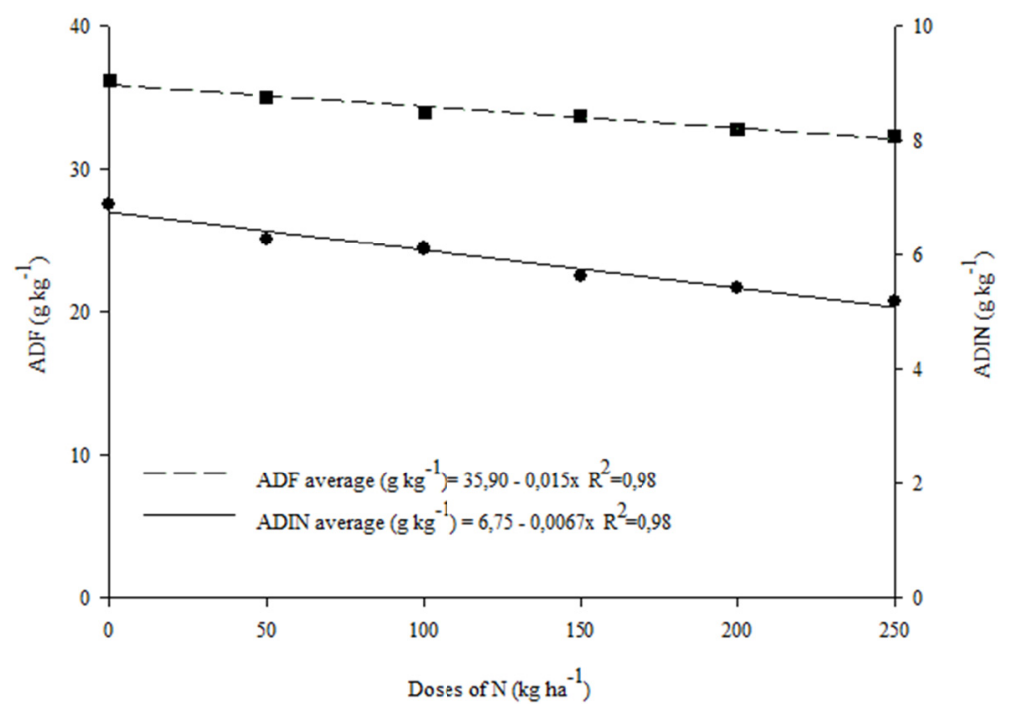

Figure 4. Average content of ADF and ADIN in the forage dry mass of grass 'Vaquero', in function of nitrogen

(N) doses, applied as swine waste, in four growth periods of the forage

The reduction in the ADF content provide improvements in the forage's digestibility. In this respect Van Soest (1994) and Magalhães (2012) mentioned that the acid detergent fiber is constituted, mainly, by lignin and cellulose present in the forage, representing the amount of fiber that is not digested by the animal, thus, the content must be around $30 \%$ because these levels influence in the food digestibility

The ADF results were superior to the ones reported by Junior et al. (2012), studying the bromatological composition of hay from Cynodon nlemfuensis, obtained ADF average content of $45.1 \mathrm{~g} \mathrm{~kg}^{-1}$.

In a study carried with grass 'Tifton 85', Brachiaria brizantha cv. 'piatã' and pigeon pea, Neres et al. (2012), observed crescent ADF content, which corroborates with the present study, when the treatments received nitrogen fertilization. 
The indigestible nitrogen in acid detergent (ADIN) obtained in the present study showed a negative linear behavior, since there was a decrease in the ADIN content in the grass 'Vaquero' with the increase in the nitrogen dose.

The ADIN content of the grass 'Vaquero', ranged between 5.07 up to $6.75 \mathrm{~g} \mathrm{~kg}^{-1}$, in the aerial part, and presented the maximum estimated point in the treatment of $0 \mathrm{~kg} \mathrm{ha}^{-1}$ (control), with a content of $6.75 \mathrm{~g} \mathrm{~kg}^{-1}$. Each $50 \mathrm{~kg}$ $\mathrm{ha}^{-1}$ of nitrogen applied a decrease of $0.33 \%$ in the ADIN content occur in the 'Vaquero' forage (Figure 4).

The ADIN contents decreased with the nitrogen fertilization from 6.75 to $5.07 \%$, from the lower to the higher dose, respectively. These ADIN results coincide with the ones found by Sales et al. (2008), studying crescent levels of urea in the forage Brachiaria brizantha cv 'Marandu', because when increasing the doses of urea, of $0 \%$ of urea $\left(5.13 \mathrm{~g} \mathrm{~kg}^{-1} \mathrm{ADIN}\right)$ of $1.6 \%$ of urea $\left(4.16 \mathrm{~g} \mathrm{~kg}^{-1}\right.$ of ADIN), with $3.2 \%$ of urea $\left(3.50 \mathrm{~g} \mathrm{~kg}^{-1} \mathrm{ADIN}\right)$ and with $4,8 \%$ of urea $\left(2.53 \mathrm{~g} \mathrm{~kg}^{-1} \mathrm{ADIN}\right)$, there was a decrease in the ADIN content. The ADIN results were superior to the ones reproduced by Castagnara et al. (2011a), studying the forage 'Tifton 85 ' during winter time, found ADIN contents of $3.1 \mathrm{~g} \mathrm{~kg}^{-1}$ at 42 of regrowth.

With respect to that, Viana et al. (2011) attributed the reduction in the ADIN content caused by the nitrogen fertilization, which was also observed in this study, as a contra balance by the increase in the wall lignification and, in the presence of an adequate nitrogen fertilization, there is a reduction in the ADIN content, causing an increase in the growth of new tissues for the plant. According to this author, the tendency is to slightly reduce the dry mass digestibility, which corroborates with the study of Van Soest (1994), who mention that the ideal content for ADIN in the dry mass are between 3 and $15 \mathrm{~g} \mathrm{~kg}^{-1}$, being these variations considered normal.

\subsection{Lignin}

In the average of all cuts, there was a negative linear effect of the $\mathrm{N}$ levels over the lignin percentage in the grass 'Vaquero'. Thus, the highest percentage of lignin was obtained in the dose of $0 \mathrm{~kg} \mathrm{ha}^{-1}$ of nitrogen, being it of $13.74 \mathrm{~g} \mathrm{~kg}^{-1}$ (Figure 5).

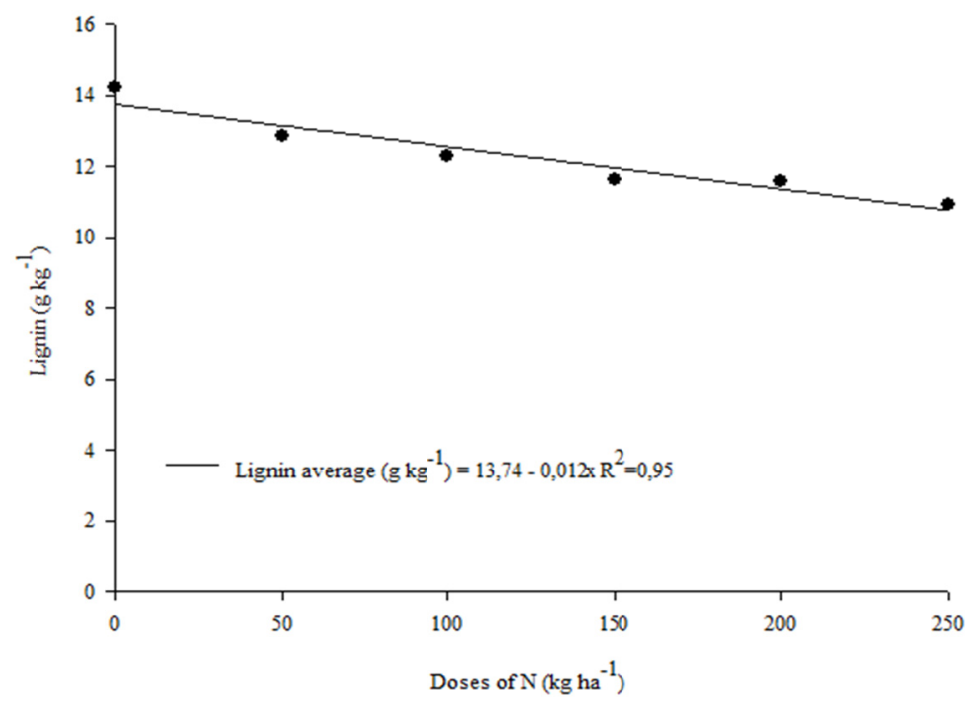

Figure 5. Average content of lignin in the forage dry mass of grass 'Vaquero', in function of nitrogen $(\mathrm{N})$ doses, applied as swine waste, in four growth periods of the forage

For the average lignin content, it was observed a reduction tendency with increase of the nitrogen dose, that is, for each $50 \mathrm{~kg} \mathrm{ha}^{-1}$ of nitrogen applied a decrease of $0.6 \mathrm{~g} \mathrm{~kg}^{-1}$ in the lignin content of the grass 'Vaquero'.

As it can be seen in Figure 5, there was a decrease in the lignin content, associated to increases in the level of N. The lignin values were superior to the ones reported by Neres et al. (2012), who obtained lignin content in the grass 'Tifton 85 ' without $\mathrm{N}$ of $7.61 \mathrm{~g} \mathrm{~kg}^{-1}$ and of $7.42 \mathrm{~g} \mathrm{~kg}^{-1}$ for the same forage with application of $\mathrm{N}$, corroborating with the results obtained in the present study, when higher doses of $\mathrm{N}$ are used, because a reduction in the lignin content occur. 
The lignin results were inferior to the ones reproduced by Oliveira et al. (2014), studying the digestibility in vitro of Cynodon grasses, obtained average lignin content in the whole plant of $8.9 \mathrm{~g} \mathrm{~kg}^{-1}$ for the grass 'Vaquero' and of $7.6 \mathrm{~g} \mathrm{~kg}^{-1}$ for the forage 'Tifton 85'.

The acid detergent fiber content (ADF) are related to the lignin content of the forage, because they determine this fiber digestibility, the small the ADF content, small will be the lignin content and, consequently, better the food digestibility (Santos et al., 2008), that corroborates with the study of Van Soest (1994), who affirmed that the lignin limits the digestibility of the other fibrous fractions.

The lignin behavior was also reported by Rogerio et al. (2007) who confirmed that high lignin content in the ruminant's diet can limit the availability of the dietetic protein, as well as reduce the consumption of dry mass by the animals.

\subsection{Ether Extract}

In the average of all cuts, the ether extract content from the grass 'Vaquero', adjusted to the crescent linear model, in function of the nitrogen doses and, ranged from 1.78 up to $2.20 \mathrm{~g} \mathrm{~kg}^{-1}$ in the aerial part. Each $50 \mathrm{~kg} \mathrm{ha}^{-1}$ of nitrogen applied there was an increase of $0.085 \mathrm{~g} \mathrm{~kg}^{-1}$ in the ethereal extract of the forage 'Vaquero' (Figure 6).

The ether extract was inferior to the observed by Silva et al. (2009), who studying the nutrients digestibility in bulk food, found average content of ether extract of $1.5 \mathrm{~g} \mathrm{~kg}^{-1}$ for the forage 'Coastcross'.

In the treatment of $250 \mathrm{~kg} \mathrm{ha}^{-1}$, it was obtained higher average ether extract content, in which the dose of $2.20 \mathrm{~g}$ $\mathrm{kg}^{-1}$ was found; The ether extract value in the present study, remained similar to the obtained by Santos et al. (2008), who studying the forages 'Tifton 85', 'Tanzânia' and 'Marandu', during summertime, obtained ether extract values of $1.9 \mathrm{~g} \mathrm{~kg}^{-1}$ for the forage 'Tifton 85 ', $1.7 \mathrm{~g} \mathrm{~kg}^{-1}$ for the 'Tanzânia' and $1.6 \mathrm{~g} \mathrm{~kg}^{-1}$ for the 'Marandu'.

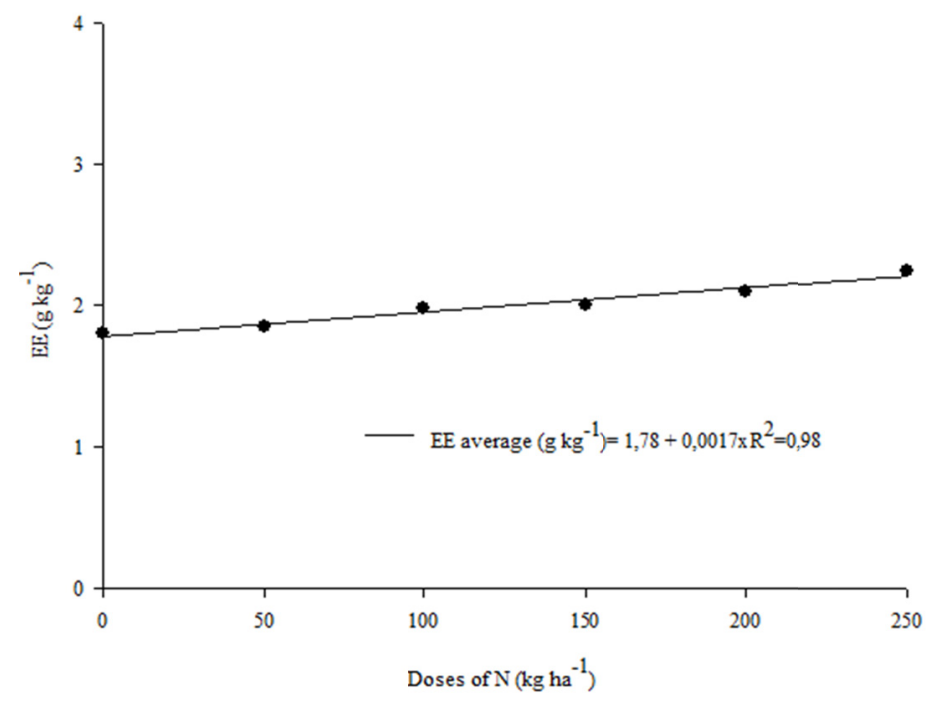

Figure 6. Average content of ether extract in the forage of grass 'Vaquero', in function of nitrogen $(\mathrm{N})$ doses, applied as swine waste, in four growth periods of the forage

The results of ether extracts were inferior to the ones found by Porto et al. (2009), studying tropical forage, obtained average ether extracts of $1.39 \mathrm{~g} \mathrm{~kg}^{-1}$ for the forage 'Tanzânia', of $1.43 \mathrm{~g} \mathrm{~kg}^{-1}$ for the grass 'estrela' and of $1.39 \mathrm{~g} \mathrm{~kg}^{-1}$ for the forage 'Marandu'.

The EE contents were similar to the ones observed by Andrade et al. (2012), that studying the growth and bromatological composition of 'Tifton 85' and 'Vaquero' with fertirrigation, obtained values of ether extract of 2.37 for the 'Vaquero' and $2.17 \mathrm{~g} \mathrm{~kg}^{-1}$ for the 'Tifton 85 '.

According to Van Soest (1994), most pastures present a small amount of EE in their composition, being able to reach up to $3.5 \mathrm{~g} \mathrm{~kg}^{-1}$ in the DM, this is a positive factor since the cattle have tolerance to levels of up to $7.0 \mathrm{~g}$ $\mathrm{kg}^{-1}$ in the DM of the diet. 
Also, for the EE concentrations in the dry mass, Rodrigues Júnior et al. (2015) mention that in tropical forage this content may vary up to $4 \mathrm{~g} \mathrm{~kg}^{-1}$. In this sense, Souza et al. (2010) observed that the inclusion of the ether extract in the animal diet cannot exceed $6 \mathrm{~g} \mathrm{~kg}^{-1}$, to avoid compromising the dry mass consumption, avoiding then deleterious effects in the animal's digestion.

\subsection{Dry Mass Yield}

The response of the total dry mass yield of 'Vaquero' in function of nitrogen doses was adjusted to crescent linear model and, ranged from 3080.57 to $4520.57 \mathrm{~kg} \mathrm{ha}^{-1}$ on the aerial part, that is, there is an estimated increase of $46.74 \%$ in the 'Vaquero' dry mass yield, when changed from 0 to $250 \mathrm{~kg}$ of swine wastes per hectare.

The results of total dry mass yield were inferior to the ones found by Oliveira et al. (2000), that verified that the grass 'Tifton 85', in different regrowth stages, reached a dry mass production ranging from 3.1 to $12.3 \mathrm{t} \mathrm{ha}^{-1}$.

The results of total DM productivity (Figure 8), reveal inferior values to the ones reported by Matos et al. (2008). According to these authors, the 'Tifton 85', submitted to different applications of swine wastes, presented a linear increase in the dry mass yield, with values from 7.7 to $15.4 \mathrm{t} \mathrm{ha}^{-1}$.

In this scenario, the increases in the DM total yield observed in this study is related to the nitrogen fertilization, which caused an increase in the regrowth vigor, in the pasture regrowth capacity and in the development of the aerial part of forages (Silva et al., 2012).

In Figure 7 are presented the data of total productivity $\left(\mathrm{kg} \mathrm{ha}^{-1}\right)$ of this experiment, being that the regression analysis revealed that the higher dry mass productivity of the grass 'Vaquero' was of $4520.57 \mathrm{~kg} \mathrm{ha}^{-1}$ in the dry mass of treatment with $250 \mathrm{~kg} \mathrm{ha}^{-1}$.

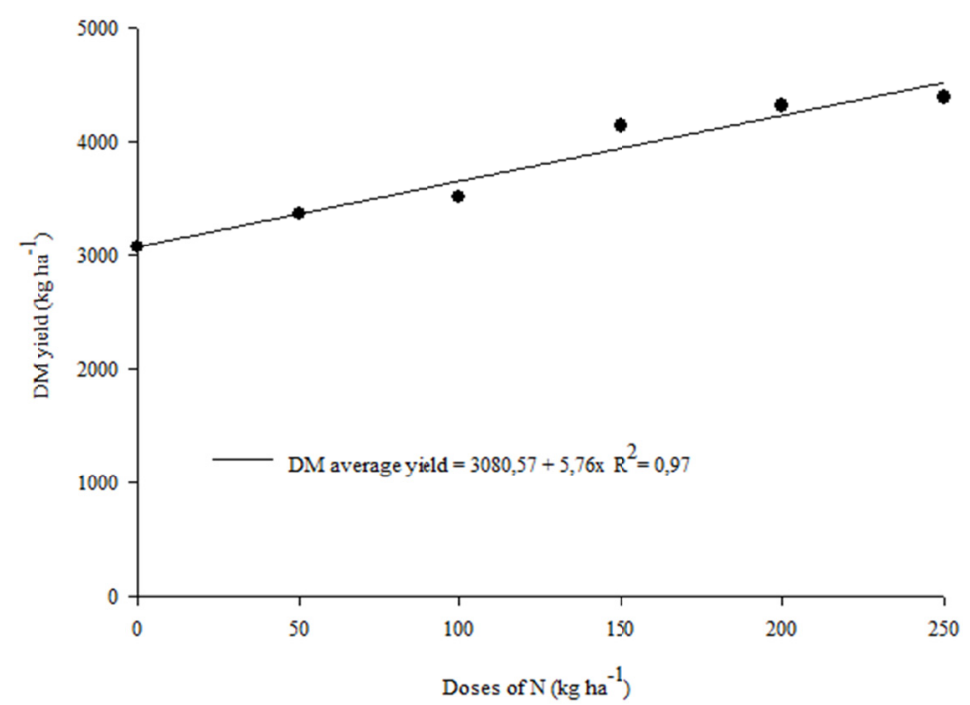

Figure 7. Total yield $\left(\mathrm{kg} \mathrm{ha}^{-1}\right)$ in the forage dry mass of grass 'Vaquero', in function of nitrogen $(\mathrm{N})$ doses, applied as swine waste, in four growth periods of the forage

The total DM yield of this study remained inferior to the obtained by Rocha et al. (2000) that studying the dry mass of tropical grasses, found a DM total yield of 3.67 up to $10.65 \mathrm{t} \mathrm{ha}^{-1}$ for the forage 'Coastcross', of 4.79 up to $10.99 \mathrm{t} \mathrm{ha}^{-1}$ for the forage 'Tifton 85 ' and of 3.41 up to $8.79 \mathrm{t} \mathrm{ha}^{-1}$ for the forage 'Tifton 68 ' for doses of 0 and $400 \mathrm{~kg} \mathrm{ha}^{-1}$ of nitrogen.

The results of total DM production were inferior to the ones found by Quaresma et al. (2011), that when evaluating the bromatological composition of 'Tifton 85 ' forage submitted to doses of $\mathrm{N}$, found an accumulated yield of $11735.35 \mathrm{~kg} \mathrm{ha}^{-1}$ of DM, when it received a dose of $240 \mathrm{~kg} \mathrm{ha}^{-1}$ of $\mathrm{N}$ as urea in cover.

\section{Conclusions}

The different nitrogen doses, applied as swine wastes in the forage 'Vaquero', influenced in the bromatological composition and in the total dry mass yield, providing and increase in the average content of CP, DM and EE.

The increase in the nitrogen doses improves the nutritional quality of the grass 'Vaquero', once it promotes decreases in the NDF, ADF content and increases in the CP and DM contents. 
The Cynodon dactylon cv. 'Vaquero' has potential to respond to nitrogen doses higher than $250 \mathrm{~kg} \mathrm{ha}^{-1}$.

In the DM yield of the grass 'Vaquero' there is an estimated increase of $46.74 \%$ in the DM of 'Vaquero', when going from 0 to $250 \mathrm{~kg}$ of swine waste per hectare.

\section{References}

Andrade, A. S., Drumond, L. C. D., Appelt, M. F., Moreira, D. D., Araújo, F. C. de, \& God, P. I. V. G. (2012). Growth and chemical composition of Tifton 85 and Vaquero in fertigated pastures. Global Science and Technology, 5(2), 56-68.

AOAC (Association of Official Analytical Chemists). (1990). Official Methods of Analysis (15th ed., p. 1117). Virginia: Arlington.

Arruda, C. A. O., Alves, M. V., Mafra, A. L., Cassol, P. C., Albuquerque, J. A., \& Santos, J. C. P. (2010). Pig slurry application and structure of a red latosol under no tillage. Ciência e Agrotecnologia, 34(4). https://doi.org/10.1590/S1413-70542010000400002

Barbero, L. M., Cecato, U., Lugão, S. M. B., Gomes, J. A. N., Limão, V. A., Abrahão, J. J. S., \& Roma, C. F. C. (2010). Animal production and nutritive value of a Coastcross pasture mixed with forage peanut. Arquivo Brasileiro de Medicina Veterinária e Zootecnia, 62(3), 645-653. https://doi.org/10.1590/S0102-0935201000 0300021

Camargo, S. C., Mesquita, E. E., Castagnara, D. D., Neres, M. A., \& Oliveira, P. S. R. de. (2011). The effect of the application of swine manure on mineral concentration in the aerial part of Tifton 85. Scientia Agraria Paranaensis, 10(2), 51.

Carvalho, D. M. G. de, Silva Cabral, L. da, Zervoudakis, J. T., Arnoldo, T. L. Q., Benatti, J. M. B., Koscheck, J. F. W., \& Oliveira, A. A. de. (2011). Supplements for sheep maintained on Marandu grass pastures. Pesquisa Agropecuária Brasileira, 46(2), 196-204. https://doi.org/10.1590/S0100-204X2011000200012

Castagnara, D. D., Mesquita, E. E., Neres, M. A., Oliveira, P. S. R., Deminicis, B. B., \& Bamberg, R. (2011a). Nutritional value and structural characteristics of tropical grasses under nitrogen fertilization. Archivos de Zootecnia, 60(232), 931-942. https://doi.org/10.4321/S0004-05922011000400010

Castagnara, D. D., Zoz, T., Krutzmann, A., Uhlein, A., Mesquita, E. E., Neres, M. A., \& Rabello De Oliveira, P. S. (2011b). Forage yield, structural characteristics and nitrogen use efficiency in tropical forages under nitrogen fertilizer. Semina: Ciências Agrárias, 32(4), 1637-1648. https://doi.org/10.5433/1679-0359.2011 v32n $4 \mathrm{p} 1637$

Costa, K. A. P., Faquin, V., \& Oliveira, I. P. (2010). Nitrogen doses and sources on pasture recuperation of grass Marandu. Arquivo Brasileiro de Medicina Veterinária E Zootecnia, 62(1), 192-199. https://doi.org/10.1590/ S0102-09352010000100026

Embrapa (Brazilian Agricultural Research Corporation). (2006). Brazilian Soil Classification System (2nd ed., p. 306). Rio de Janeiro: Embrapa Soil.

Fukumoto, N. M., Damasceno, J. C., Deresz, F., Martins, C. E., Cóser, A. C., \& Santos, G. D. (2010). Milk yield and composition, feed intake and stocking rate of crossbread cows in tropical grasses managed in a rotational grazing system. Revista Brasileira de Zootecnia, 39(7), 1548-1557. https://doi.org/10.1590/ S1516-35982010000700022

Gerdes, L., Werner, J. C., Colozza, M. T., Possenti, R. A., \& Schammass, E. A. (2000). Evaluation of nutritive characteristics of the grasses Brachiaria brizantha cv. Marandu, Setaria sphacelata cv. Kazungula and Panicum maximum cv. Tanzânia in the seasons of the year. Revista Brasileira De Zootecnia, 29(4), 955-963. https://doi.org/10.1590/S1516-35982000000400003

Gonçalves, G. D., Santos, G. T., Jobim, C. C., Cecato, U., Damasceno, J. C., Branco, A. F., \& Silva, K. T. (2001). Determination of protein and carbohydrate fractions of Cynodon grasses in different cut age. Acta Scientiarum, 23(4), 789-794. https://doi.org/10.4025/actascianimsci.v23i0.2590

IAPAR. (2013). Climate Maps of Paraná. Londrina, Brazil. Retrieved August 24, 2018, from http://www.iapar.br/modules/conteudo/conteudo.php?conteudo=597

Junior, M. C., Jobim, C. C., Cecato, U., Santos, G. T., \& Junior, V. H. B. (2012). Dehydratation curve and chemical-bromatologic composition of stargrass (Cynodon Nlemfuensis Vanderyst) hay in function of the baling process moisture content. Semina: Ciências Agrárias, 33(6), 2411-2422. https://doi.org/10.5433/ $1679-0359.2012 \mathrm{v} 33 \mathrm{n} 6 \mathrm{p} 2411$ 
Klaus, O., Zeferin, G., Rovaris, S., Souza, S. N. M. de, \& Colombari, F. S. (2013). Productivity of Cynodon Spp. (Tifton 85) in rotational grazing areas biofertirrigados whith pig manure. Acta Iguazu, 2(2), 73-82.

Magalhães, J. A., Carneiro, M. D. S., Andrade, A. C., Pereira, E. S., Souto, J. S., Pinto, M. D. C., \& Mochel Filho, W. (2012). Nitrogen use efficiency, yield and composition of Andropogon-grass under irrigation and fertilization. Archivos de Zootecnia, 61(236), 577-588.

Marchesan, R., Paris, W., Ziech, M. F., Prohmann, P. E. F., Zanotti, J., \& Hartmann, D. V. (2013). Production and chemical composition of Tifton 85 (Cynodon Dactylon L. Pers) under continuous grazing during winter. Semina: Ciências Agrárias, 34(4), 1935-1944. https://doi.org/10.5433/1679-0359.2013v34n4p1935

Matos, A. T., Abrahão, S. S., \& Pereira, O. G. (2008). Agronomic performance of Tifton 85 (Cynodon spp) grass cultivated in constructed wetlands used in milk processing wastewater treatment. Revista Ambi-Água, Taubaté, 3(1), 43-53. https://doi.org/10.4136/ambi-agua.41

Mesquita, E. E., \& Neres, M. A. (2008). Mophogenesis and chemical composition of Panicum maximum cultivars in function of nitrogen fertilization. Revista Brasileira de Saúde d Produção Animal, 9(2), 201-209.

Mistura, C., Fonseca, D. M., Moreira, L. M., Fagundes, J. L., Morais, R. D., Queiroz, A. D., \& Ribeiro Junior, J. I. (2007). Effect of nitrogen fertilization and irrigation on the chemical composition of the leaf blade and whole plant of elephantgrass under grazing. Revista Brasileira de Zootecnia, 36(6), 1707-1714. https://doi.org/10.1590/S1516-35982007000800002

Moreira, L. M., Martuscello, J. A., Fonseca, D. M. da, Mistura, C., Morais, R. V. de, \& Júnior, J. I. (2009). Tillering, forage accumulation and bromatological composition of Brachiaria Grass under nitrogen fertilization. Revista Brasileira de Zootecnia, 38(9), 1675-1684. https://doi.org/10.1590/S1516-3598200 9000900006

Neres, M. A., Castagnara, D. D., Silva, F. B., Oliveira, P. S. R. de, Mesquita, E. E., Bernardi, T. C., \& Vogt, A. S. L. (2012). Productive, structural and bromatological characteristics of Tifton 85 and piatã grasses and of Pigeonpea cv. super n, in single or mixed. Ciência Rural, 42(5), 862-869. https://doi.org/10.1590/ S0103-84782012000500017

Neto, J. D., Santos, F. A. S., Furtado, D. A., \& Matos, J. D. (2000). Influence of precipitation and plant age on the production and chemical composition of the bufell grass. Pesquisa Agropecuária Brasileira, 35, 1867-1874. https://doi.org/10.1590/S0100-204X2000000900020

Oliveira, E. R. de, Monção, F. P., Tonissi, R. H. de, Góes, B., Gabriel, A. M. A., Lempp, B., \& Pedroso, F. W. (2014). In vitro digestibility of grass Cynodon Spp evaluated in four ages of regrowth. Agrarian, 7(23), 147-156.

Oliveira, E. R., Monção, F. P., Goes, R. H. T. B., Gabriel, A. M. A., Moura, L. V., Lempp, B., ... Tochetto, A. T. C. (2013). Rumen degradation of neutral detergent fiber grasses of the genus Cynodon Spp. in four ages of cut. Revista Agrarian, 6(20), 205-214.

Oliveira, M. D., Pereira, O. G., Garcia, R., Obeid, J. A., Cecon, P. R., Moraes, S. D., \& Silveira, P. D. (2000). Yield and nutritive value of bermudagrass 'Tifton 85 (Cynodon Spp.) at different ages of regrowth. Revista Brasileira De Zootecnia, 29(6), 1949-1960.

Pereira, E. S., Pimentel, P. G., Duarte, L. S., Mizubuti, I. Y., Araújo, G. G. L., Carneiro, M. S. de, \& Maia, I. S. G. (2010). Determination of the proteins and carbohydrates fractions and estimative of the energy value of forages and by-products in Brazilian Northeast. Semina: Ciências Agrárias, 31(4). https://doi.org/10.5433/ 1679-0359.2010v31n4p1079

Pereira, O. G., Oliveira, M. D., Pinto, J. C., Santos, M. E. R., Ribeiro, K. G., \& Cecon, P. R. (2011). Growth analysis of Coastcross-1 bermudagrass grown under nitrogen doses at two regrowth ages. Revista Brasileira de Zootecnia, 40(10), 2121-2128. https://doi.org/10.1590/S1516-35982011001000008

Porto, P. P., Deresz, F., Santos, G. D., Lopes, F. C. F., Cecato, U., \& Cóser, A. C. (2009). Milk production, milk composition, intake and digestibility of tropical forages under intermittent grazing system. Revista Brasileira De Zootecnia, 38(8), 1422-1431. https://doi.org/10.1590/S1516-35982009000800005

Quaresma, J. P. S. de, Almeida, R. G. de, Abreu, J. G. de, Cabral, L. S. da, Oliveira, M. A., \& Carvalho, D. M. G. de. (2011). Forage yield and chemical composition of Tifton 85 bermudagrass (Cynodon spp.) subjected to 
nitrogen levels. Acta Scientiarum. Animal Sciences, 33(2), 145-150. https://doi.org/10.4025/actascianimsci. v33i2.9261

Rocha, G. P., Evangelista, A. R., De Lima, J. A., \& Rosa, B. (2002). Nitrogen doses on grasses of the Cynodon genus. Ciência Animal Brasileira, 3(1), 1-9.

Rocha, G. P., Evangelista, A., \& Lima, J. D. (2000). Nitrogen in dry matter production, crude protein content and yield of tropical grasses. Pasturas Tropicales, 22(1), 4-8.

Rodrigues Júnior, C. T., Carneiro, M. D. S., Magalhaes, J., Pereira, E., Rodrigues, B., Costa, N. D. L., \& Castro, K. D. C. (2015). Production and chemical composition of Marandu grass in diferente periods of stockpiled and utilization. Semina: Ciências Agrárias, 36, 2141-2154. https://doi.org/10.5433/1679-0359.2015v36n3 Sup11p2141

Rodrigues, R. C., Lima, D. D. O. S., Silva Cabral, L. da, Melo Plese, L. P. de, Scaramuz, W. L. M. P., Utsonomya, T. C. A., \& Jesus, A. P. R. de. (2012). Production and morphophysiology of palisadegrass Brachiaria Brizantha Cv. Xaraés under nitrogen and phosphorus fertilization. Revista Brasileira de Agropecuária Sustentável, 2(1).

Rogério, M. C. P., Borges, I., Neiva, J. N. M., Rodriguez, N. M., Pimentel, J. C. M., Costa, J. B., .. Carvalho, F. C. (2007). Nutritive value of pineapple by-product (Ananas Comosus L.) in diets for sheep. 1. intake, apparent digestibility, energetic and nitrogenous balance. Arquivos Brasileiros de Medicina Veterinária e Zootecnia, 59, 773-781. https://doi.org/10.1590/S0102-09352007000300032

Sales, M. F. L., Paulino, M. F., Valadares Filho, S. D. C., Porto, M. O., Moraes, E., \& Barros, L. D. (2008). Urea levels in multiple supplements for finishing beef cattle on palisade grass pasture during the rainy to dry transition. Revista Brasileira de Zootecnia, 37(9), 1704-1712. https://doi.org/10.1590/S1516-3598200800 0900025

Santana, G. S., Bianchi, P. P. M., Morita, I. M., Isepon, J. O., \& Fernandes, F. M. (2010). Production and bromatologic composition of grass-mombaça (Panicum maximum Jacq.), submitted to different sources and doses of acidity corrective. Semina: Ciências Agrárias, 31(1), 241-246. https://doi.org/10.5433/1679-0359. $2010 \mathrm{v} 31 \mathrm{n} 1 \mathrm{p} 241$

Santos, N. L., Silva, M. D., \& Chaves, M. A. (2008). Supplementary irrigation effect on the productive potential of the Tifton 85, Tanzânia and Marandu grasses in the southwest of Bahia state. Ciência Animal Brasileira, 9(4), 911-922.

Silva, D. J., \& Queiroz, A. C. (2006). Food Analysis: Chemical and Biological Methods (p. 235). Ed UFV.

Silva, M. S. J. da, Jobim, C. C., Nascimento, W. G. do, Ferreira, G. D. G., Silva, M. S., \& Três, T. T. (2013). Estimate of production and nutritional value of Stylosanthes Hay Cv. Campo grande. Semina: Ciências Agrárias, 34(3), 1363-1380. https://doi.org/10.5433/1679-0359.2013v34n3p1363-1380

Silva, T. C. da, Perazzo, A. F., Macedo, C. H. O., Batista, E. D., Pinho, R. M. A., Bezerra, H. F. C., \& Santos, E. M. (2012). Morphogenesis and structure of Brachiaria Decumbens submitted to cut management and nitrogen fertilization. Archivos de Zootecnia, 61(233), 91-102. https://doi.org/10.4321/S0004-0592201 2000100010

Silva, V. P., Almeida, F. Q., Morgado, E. S., França, A. B., Ventura, H. T., \& Rodrigues, L. M. (2009). Nutrient digestibility of forage feed determined using mobile bag technique in horses. Revista Brasileira de Zootecnia, 38(1), 82-89. https://doi.org/10.1590/S1516-35982009000100011

Souza, A. R. D. L., Medeiros, S. R. de, Graça Morais, M. da, Oshiro, M. M., \& Júnior, R. A. D. A. T. (2010). High fat diet and performance of young bulls from different genetic groups in confinement. Pesquisa Agropecuária Brasileira, 44(7), 746-753. https://doi.org/10.1590/S0100-204X2009000700015

Systat Software. (2011). Sigmaplot for Windows Version 12.0. San Jose: Systat Software Inc.

Taiz, L., \& Zeiger, E. (2013). Fisiologia Vegetal (5th ed., p. 918). Porto Alegre, Artmed.

Van Soest, P. J. (1994). Lignin. In P. J. Van Soest (Ed.), Nutritional Ecology of the Ruminant (2nd ed., pp. 177-195). Ithaca: Cornell University, Cornell University Press. https://doi.org/10.7591/9781501732355

Van Soest, P. J. (1994). Nutritional Ecology of the Ruminant (p. 476). Ithaca: Constock Publishing Associates. https://doi.org/10.7591/9781501732355 
Van Soest, P. J., Robertson, J. B., \& Lewis, B. A. (1991). Methods for dietary fiber, neutral detergent fiber and no starch polysaccharides in relation to animal nutrition. Journal of Dairy Science, 74, 3583-3597. https://doi.org/10.3168/jds.S0022-0302(91)78551-2

Viana, M. C. M., Freire, F. M., Ferreira, J. J., Macêdo, G. A. R., Cantarutti, R. B., \& Mascarenhas, M. H. T. (2011). Nitrogen fertilization on yield and chemical composition of signalgrass under rotational grazing. Revista Brasileira De Zootecnia, 40(7), 1497-1503. https://doi.org/10.1590/S1516-35982011000700014

Vitor, C. M. T., Fonseca, D. D., Cóser, A. C., Martins, C. E., Nascimento Júnior, D., \& Ribeiro Júnior, J. I. (2009). Dry matter production and nutritional value of elephant grass pasture under irrigation and nitrogen fertilization. Revista Brasileira de Zootecnia, 38(3), 435-442. https://doi.org/10.1590/S1516-35982009 000300006

\section{Copyrights}

Copyright for this article is retained by the author(s), with first publication rights granted to the journal.

This is an open-access article distributed under the terms and conditions of the Creative Commons Attribution license (http://creativecommons.org/licenses/by/4.0/). 